\title{
O REGIME JURÍDICO DAS LICITAÇÕES NO BRASIL E O MERCOSUL
}

\author{
Cesar A. Guimarães Pereira*
}

I - Introdução. II - O regime constitucional das licitações no Brasil. III - O regime legal das licitações no Brasil. IV - $O$ tratamento de licitantes estrangeiros no Brasil. $V-O$ estado atual do tema no âmbito do Mercosul. VI - Conclusão

\section{I - Introdução}

1. Dentro do tema geral do Congresso', esta exposição tratará da seleção de particulares a ser contratados pela Administração Pública.

Parece-me que este tópico é oportuno, de um lado, porque se refere a um ponto de afirmação do regime jurídico de direito público em relação aos contratos da Administração Pública. Mesmo os ditos contratos privados da Administração submetem-se, quanto à sua formação, ao regime de direito público.

De outro, trata-se de tema objeto de preocupação específica por parte dos órgãos setoriais do Mercosul. Discute-se atualmente, no âmbito de um grupo de trabalho vinculado ao Grupo Mercado Comum, o teor de um protocolo comum para o regime jurídico das compras governamentais, o que envolverá uma definição sobre o procedimento licitatório (ou seja, sobre a seleção de contratados).

2. A seleção de contratados é um tópico da atuação contratual do Estado que, a meu ver, afirma a existência de um plexo de princípios e normas peculiares, não aplicáveis às relações privadas e que caracterizam um regime jurídico próprio das contratações da Administração.

* Advogado em Curitiba (PR), Brasil. Mestre e Doutorando em Direito do Estado pela Pontificia Universidade Católica de São Paulo.

1 Este trabalho deriva de exposição apresentada no III Congresso da Associação de Direito Público do Mercosul e IV Jornadas de Direito Administrativo dos Países do Mercosul, ocorridos entre 25 e 27 de outubro de 2000, em Montevidéu (Uruguai), sob o tema geral "Direito Público e Direito Privado". 
Esse tópico foi excelentemente exposto pelo professor boliviano JUAN ALBERTO MARTÍNEZ, em exposição anterior neste mesmo Congresso. Segundo MARTÍNEZ, a interferência de um aspecto privado no regime licitatório não se deve dar através da sujeição total ou parcial das compras governamentais a um regime de direito privado mas de uma integração maior entre o Poder Público e o setor privado da economia (por exemplo, através da participação dos agentes privados na elaboração de modelos de atos convocatórios de licitação).

3. Esse mesmo aspecto pode traduzir-se, no Brasil, através de iniciativas ligadas a orçamentos participativos - em que os particulares passam a exercitar atividades concretas na definição e acompanhamento das prioridades de dispêndios da Administração, inclusive, portanto, nas compras governamentais.

Em termos jurídicos, há a consagração, no Brasil, de participação privada na definição da oportunidade e no objeto de licitações em uma variedade de situações. De modo amplo, o art. 39 da Lei de Licitações (Lei $n^{\circ}$ 8.666, de 1993) prevê a realização de audiências públicas previamente à realização de licitações de grande porte (de valor superior, hoje, a cerca de US\$75 milhões ${ }^{2}$ ). É prevista de forma abrangente a fiscalização do particular interessado sobre o procedimento licitatório, podendo haver impugnação do ato convocatório (art. $41, \S 1^{\circ}$, da Lei de Licitações) e amplo acesso a informações e a acompanhamento da licitação (art. $4^{\circ}$ da Lei de Licitações).

4. Portanto, nessa matéria em particular, a inserção de um regime jurídico dito de direito privado ocorre primordialmente através da exclusão de certas atividades do âmbito de atuação do Estado.

4.1. Assiste-se hoje, não apenas no Brasil, a uma intensa transferência de setores atendidos pelo Poder Público para a exploração privada, seja através de privatização de empresas e de atividades propriamente dita, seja através da outorga de concessões ou permissões.

As contratações realizadas pelas entidades privatizadas ou pelos concessionários não se submetem ao regime de direito público, nem mesmo quanto à exigência de licitação. Isso retira do campo de incidência dessas regras uma quantidade relevante de situações.

4.2. Além disso, há a consagração de figuras jurídicas novas - como as chamadas "organizações sociais" no Brasil ${ }^{3}$ - que pretendem promover a atuação privada de interesse público. Embora possam receber, em certos casos, recursos públicos, essas entidades não se submetem a licitação em suas contratações.

2 Os valores são referidos no presente texto $\mathrm{cm}$ moeda estrangeira apenas para facilitar sua compreensão. A lei brasileira os define em moeda nacional, em valores fixos. Neste caso, por exemplo, a Lei alude a um valor de $\mathrm{R} \$ 150$ milhões.

3 Instituídas pela Lei $n^{\circ} 9.637 / 98$. Há figura similar, denominada "organização da sociedade civil de interesse público", instituída pela Lei $\mathrm{n}^{\circ}$ 9.790/99, e certas instituições anômalas, de natureza atípica, usualmente denominadas "serviços sociais autônomos" e criadas por leis especificas. 
A doutrina brasileira ${ }^{4}$ vem-se ocupando de estabelecer limites rígidos para a atuação dessas entidades, de forma a evitar que se transformem em uma fraude destinada a suprimir os controles sobre as atividades próprias do Poder Públicos.

5. Ainda assim, os contratos firmados pela Administração Pública mantêm sua relevância na economia dos nossos países. Os dispêndios da Administração são extremamente significativos. Mesmo se não o fossem, permaneceria necessário manter o rigor na seleção dos particulares a ser beneficiados pelo direito de contratar com o Estado.

Nesse ponto específico, portanto, não há interferência relevante do direito privado sobre o direito público. O regime jurídico da seleção de contratados pelo Estado é rigorosamente público. Mesmo nos casos em que a licitação é legalmente dispensável em face do valor reduzido da contratação, a escolha do contratante

6. Esta exposição pretende transmitir uma visão ampla do sistema de seleção de contratados hoje vigente no Brasil, o que permitirá uma reflexão sobre o caminho a ser percorrido para uma harmonização de regimes nessa área.

Note-se que nenhuma das propostas até agora desenvolvidas no Mercosul alude à necessidade de uniformizaçāo legislativa. Defende-se apenas a definição de pontos comuns e, principalmente, o tratamento não discriminatório e até mesmo preferencial em relação aos produtos oriundos dos demais Estados-Membros.

A questão, portanto, será definir em que medida será necessário algum ajuste na legislação nacional de cada Estado-Membro para que se possam realizar os objetivos fundamentais da harmonização de regimes.

\section{II - O regime constitucional das licitações no Brasil}

7. A compreensão do regime brasileiro acerca da seleção de contratados pelo Poder Público deve partir de dois pontos fundamentais.

7.1. O primeiro é o de que o Brasil é uma federação, e uma federação peculiar.

Como em qualquer outra, há competências normativas do ente central (União) e dos entes locais (Estados e Distrito Federal). Isso nos exige, desde logo, buscar na Constituição Federal as regras sobre a partilha de competências entre a União, de um lado, e os Estados-Membros e o Distrito Federal, de outro.

Porém, a Constituição Federal alude a que a federação brasileira é também integrada pelos Municípios, aos quais a Constituição atribui autonomia e competências legislativas próprias.

4 Confira-se, sobre o tema, CELSO ANTÔNIO BANDEIRA DE MELLO, Curso de Direito Administrativo, $12^{2}$ ed., Malheiros, 2000, pp. 192/198 (organizações sociais) e 198/199 (organizações da sociedade civil de interesse público).

5 Sobre essa possibilidade de fraude, com referências a situaçōes específicas e aos problemas delas derivados, confira-se MARIA CRISTINA CESAR DE OLIVEIRA DOURADO, O Sistema Remuneratório dos Senvidores Públicos e a Emenda Constitucional n ${ }^{\circ} 19 / 98$, exposição apresentada ao I Congresso Brasileiro de Direito Público, ocorrido em 26 a 28 de abril de 2000, em São Paulo (SP), ainda inédito. 
Portanto, as regras acerca da seleção de contratados - que são diretamente vinculadas à autonomia administrativa de cada ente político - podem ser produzidas, em certa medida, não apenas pela União mas também por Estados, Distrito Federal e Municípios.

7.2. Essa competência normativa dos entes políticos seria apta a ocasionar uma grande dificuldade de conhecimento das regras vigentes, não fosse o regime constitucional específico das licitações no Brasil - e aqui nós estamos no segundo ponto de partida para a investigação do tema.

A Constituição brasileira, vigente desde 1988 e emendada, neste tópico específico, em 1998, estabelece princípios e regras significativos sobre a abrangência e a disciplina das licitações.

7.2.1. O art. 22, XXVII, da Constituição, determina que compete privativamente à União legislar sobre "normas gerais de licitação e contratação, em todas as modalidades, para as administrações públicas diretas, autárquicas e fundacionais da União, Estados, Distrito Federal e Municípios, obedecido o disposto no art. 37. $X X I$, e para as empresas públicas e sociedades de economia mista, nos termos do art. $173, \S 1^{\circ}, I I I^{\prime}$.

Disso deriva, desde logo, que a competência normativa dos Estados, Distrito Federal e Municípios neste campo é muito menor do que se poderia supor em um exame inicial. As normas gerais são definidas privativamente pela União e são vinculantes para os demais entes. As competências locais são restritas às peculiaridades não disciplinadas nas normas gerais.

Assim, a relevância da legislação local para o regime das licitações no Brasil é secundária.

A competência para a edição de normas gerais vem sendo exercitada há longo tempo pela União. Houve uma sucessão de textos legislativos, que culminou, em 1993, com a edição da atual Lei de Licitações e Contratos Administrativos (Lei $n^{\circ}$ 8.666/93). A União exercitou essa sua competência também em textos legislativos esparsos. Os mais significativos são a Lei de Concessões, de 1993 (Lei $n^{\circ} 8.987 / 95$ e Lei $n^{\circ}$ 9.074/95), e a Medida Provisória ${ }^{\circ} 2.026^{6}$, de junho de 2000 , que instituiu uma nova modalidade licitatória.

7.2.2. O conteúdo fundamental do regime licitatório no Brasil é dado pelo art. 37, inciso XXI, da Constituição, cuja redação é a seguinte: "Ressalvados os casos especificados na legislação, as obras, serviços, compras e alienaçōes serão contratados mediante processo de licitação pública que assegure igualdade de condições

6 É extremamente questionável a possibilidade de regras dessa natureza ser veiculadas através de medida provisória, instrumento previsto na Constituição Federal como de índole excepcional, vinculado a casos de relevância e urgência (art. 62). Em duas ocasiōes recentes, o Supremo Tribunal Federal, em decisões plenárias e por unanimidade, suspendeu a eficácia de textos de medidas provisórias sob o fundamento de ausência de urgência no tratamento legislativo da matéria (ADIncMC 1.753-DF, rel. Min. Sepúlveda Pertence, j. 16.4.1998; e ADIncMC 1.910-DF, rel. Min. Sepúlveda Pertence, j. 22.4.1999). Parece-nos cabível reconhecer a ausência de urgência também no caso da Medida Provisória $n^{\circ}$ 2.026/2000 aqui referida. Trata-se de matéria passível de tratamento legislativo apenas através de lei formal. 
a todos os concorrentes, com cláusulas que estabeleçam obrigações de pagamento, mantidas as condições efetivas da proposta, nos termos da lei, a qual somente permitirá as exigências de qualificação técnica e econômica indispensáveis à garantia do cumprimento das obrigações".

Como se percebe, esse dispositivo contém uma variedade de determinações acerca do conteúdo da disciplina das licitações.

Desde logo, define que, em geral, as contratações públicas são submetidas a um requisito prévio consistente na realização de licitação. Somente não será realizada licitação nos casos ressalvados na lei. Essa é uma condição de validade dos contratos da Administração no Brasil: serão precedidos sempre de licitação ou de ato formal que reconheça o enquadramento do caso em uma das situações ressalvadas na lei.

Estabelece, além disso, um princípio que está na base da compreensão do regime licitatório no Brasil: a igualdade de condições entre os concorrentes. Em atenção a esse princípio, a legislação infraconstitucional brasileira ocupa-se de disciplinar minuciosamente o procedimento licitatório, com o objetivo de que todos os licitantes tenham condições de definir de modo preciso os requisitos que deverão preencher e os critérios segundo os quais suas propostas serão examinadas. A preocupação com a isonomia é tão intensa que, por vezes, conduz a Administração a frustrar o próprio interesse público, adotando posição excessivamente formalista em nome da proteção da competitividade da licitação.

Outro ponto fundamental, que também está na base do regime das contratações públicas no Brasil, é a consagração da manutenção das condições efetivas da proposta durante toda a execução do contrato. Com isso, há proteção constitucional ao equilíbrio econômico-financeiro do contrato administrativo, assegurando-se ao contratado a coletivização dos riscos extraordinários envolvidos no contrato. Essa regra que é traduzida com maior detalhe na legislação infraconstitucional — dá ao licitante um quadro jurídico seguro para a formulação de propostas.

Por fim, o dispositivo estabelece uma limitação das exigências de qualificação técnica e econômica que podem ser estipuladas como requisito para a contratação administrativa. Permite que a Administração, para assegurar-se do cumprimento do contrato, exija a demonstração de certos requisitos de qualificação (ou habilitação, na linguagem da Lei de Licitações). Porém, prevê a proporcionalidade entre esses requisitos e seu fim: somente as exigências indispensáveis podem ser formuladas. $\mathrm{Na}$ base dessa regra também está a preservação da isonomia e do caráter competitivo da licitação.

7.2.3. A abrangência - ou a cobertura - do regime licitatório brasileiro deriva da conjugação entre os arts. $22, \mathrm{XXVII}$, e o art. $173, \S 1^{\circ}$, III, da Constituição.

$O$ primeiro estabelece que as normas gerais de licitação aplicam-se necessariamente à Administração direta, às autarquias e fundações. Quanto às sociedades de economia mista e empresas públicas, menciona que se aplica o art. $173, \S 1^{\circ}$, III, da Constituição. Segundo esse dispositivo, essas empresas estatais que explorem atividade econômica - não, portanto, as que prestam serviços públicos - poderão ter um estatuto próprio de licitações (ainda não existente), que observará apenas os princípios da Administração Pública, que inspiram aquelas normas gerais. 
Há polêmica no direito administrativo brasileiro sobre a aplicação desses dispositivos.

Como há nítida distinção de regimes constitucionais entre as empresas estatais (sociedades de economia mista e empresas públicas) que prestam serviços públicos (art. 175 da Constituição) e as que exploram atividades econômicas (art. $173 \mathrm{da}$ Constituição), parece-nos, na esteira do que afirma MARÇAL JUSTEN FILHO?, que o regramento mais simplificado somente poderia aplicar-se a essas últimas, que exploram atividade econômica. As empresas estatais que prestam serviços públicos estão, em qualquer caso, sujeitas integralmente às normas gerais de licitações. Além disso, não havendo ainda lei que estabeleça o regramento simplificado das empresas estatais, hoje aplicam-se a todas indistintamente as normas gerais de licitações ${ }^{8}$ (afinal, o art. $1^{\circ}$, parágrafo único, da Lei de Licitações, que não foi revogado nem alterado, submete a essas normas toda a Administração direta e indireta) ${ }^{9}$.

7.2.4. Finalmente, há regra especial no art. 175 da Constituição, segundo o qual a outorga de concessão ou permissão de serviços públicos será sempre realizada mediante licitação.

Trata-se de regra de definição objetiva de cobertura do regime licitatório.

8. Esse é o desenho constitucional específico do regime de seleção de contratados no Brasil. Há regras estritas sobre a competência para a edição de normas infraconstitucionais, sobre a cobertura (em termos subjetivos e objetivos) e sobre o conteúdo fundamental da disciplina da licitação.

Mas o regime constitucional não se exaure nisso. Há princípios constitucionais gerais, definidos nos valores e objetivos fundamentais da República (arts. $1^{\circ} \mathrm{e} 3^{\circ} \mathrm{da}$ Constituição). Há direitos individuais fundamentais consagrados em inúmeros incisos do art. $5^{\circ}$ da Constituição. Há princípios específicos da Administração Pública, definidos no art. 37 da Constituição Federal. Há uma disciplina minuciosa acerca da intervenção do Estado na economia e dos princípios que regem a ordem econômica no Brasil (arts. 170 a 174 da Constituição). Há até mesmo a previsão de requisitos específicos relacionados com a proteção do meio ambiente (art. $225, \S 1^{\circ}$, IV, da Constituição).

A conjugação desses princípios e regras constitucionais compõe o quadro geral do regime licitatório no Brasil.

7 Comentários à Lei de Licitações e Contratos Administrativos, $7^{\mathrm{a}}$ ed., Malheiros. 2000, pp. 22/25.

$8 \mathrm{O}$ art. 24, parágrafo único, da Lei de Licitações atualmente estabelece um limite específico, mais elevado, para a dispensa de licitação em face do valor da contratação no caso das sociedades de economia mista e empresas estatais. Também a existência dessa regra, conquanto especial frente ao regime geral, reafirma a aplicação das normas gerais veiculadas na Lei de Licitaçôes a esses entes.

9 Também nesse sentido, MARÇAL JUSTEN FILHO, ob. cit., p. 24. Note-se que há regras próprias, como a Lei Geral de Telecomunicaçōes (Lei $n^{\circ}$ 9.472/97) acerca do regime de contratos da ANATEL. que estabelecem disciplinas específicas para certos entes da Administração. Note-se, ainda, que nem todos os contratos das empresas estatais que exploram atividade econômica são sujeitos a licitação, como esclarece CELSO ANTÔNIO BANDEIRA DE MELLO (ob. cit.. pp. 166/168). 
9. Em aplicação desse regime geral, a Lei de Licitações define que as contratações públicas no Brasil conduzem-se por um de dois caminhos possíveis. Ou o caso é enquadrado em uma hipótese legal de ausência de licitação ou a licitação é obrigatória.

Não há qualquer liberdade na seleção de contratados pelo Poder Público. Mesmo quando há aparente atribuição de alguma esfera de liberdade, a Administração é submetida aos princípios constitucionais gerais e aos específicos da função administrativa.

10. A Lei de Licitações prevê duas grandes categorias de ausência de licitação: a inexigibilidade de licitação, referida no art. 25 , e a dispensa de licitação, prevista no art. 24.

10.1. A inexigibilidade é prevista em uma fórmula ampla e aberta, que define ser inexigível a licitação quando for inviável a competição, especialmente em face da singularidade do objeto a ser contratado.

É o caso, por exemplo, de contratação de notórios especialistas para trabalhos técnicos ou de um artista consagrado para a realização de uma obra ou espetáculo. A lei prevê, de modo exemplificativo, alguns casos mas a norma é aberta para casos não expressamente previstos.

10.2. Os casos de dispensa são taxativamente previstos. São casos em que a competição, embora possível, é legalmente reconhecida como inconveniente para o interesse público. São hipóteses como as de contratos de valor reduzido, de emergência ou a de licitação sem interessados, por exemplo.

11. Isso confirma que não há livre escolha de contratados pelo Poder Público. A Constituição brasileira consagra a impessoalidade como princípio da Administração. Nem a vontade do agente público nem as características pessoais do particular contratado podem ser fatores determinantes para a contratação.

Mesmo as situações de discricionariedade são restritas. Haverá alguma esfera para apreciação subjetiva, em certa medida, na fixação do objeto do contrato a ser celebrado. Como essa fixação é sujeita aos princípios da Administração Pública, especialmente a proporcionalidade e a razoabilidade, também aqui a discrição, no caso concreto, é extremamente restrita.

12. Uma vez fixado o objeto do contrato, o campo para escolhas próprias da Administração torna-se ainda menor. A decisão entre a realização ou não de licitação é estritamente vinculada.

O que se admite, apenas, é que, nos casos de dispensa de licitação, ainda assim a Administração opte por realizá-la (ou que, havendo hipótese de inexigibilidade, decida promover uma consulta menos formal a diversos possíveis fornecedores).

12.1. No caso de inexigibilidade de licitação, o próprio objeto do contrato, por sua singularidade, já define o contratado a ser escolhido, o que suprime qualquer discricionariedade nessa fase.

12.2. Nos casos de dispensa, a hipótese de ausência de licitação pode-se caracterizar antes de definido o contratado (como ocorre no caso de emergência, por exemplo). 
Mesmo assim, a Administração deve adotar medidas para reduzir tanto quanto possível qualquer subjetividade na escolha do contratado, realizando consultas simplificadas ou algum outro mecanismo de eleição impessoal (como seria um sorteio). Além disso, sempre será obrigada a admitir qualquer eventual interessado na contratação em termos mais vantajosos para a Administração, que porventura tome conhecimento da necessidade da Administração e se ofereça para a contratação direta (desde que preencha condições exigidas razoavelmente para a contratação). Somente será admissível uma escolha discricionária quando absolutamente comprovada, por ato sempre motivado, a impossibilidade de disputa entre eventuais interessados.

12.3. O art. 26 da Lei de Licitações disciplina o procedimento da dispensa e da inexigibilidade de licitação.

Através de regras de motivação e publicidade, restringe fortemente qualquer interferência de aspectos não inteiramente sindicáveis na escolha dos contratados.

Excluem-se dessas regras específicas apenas os casos de dispensa por valor reduzido (até o equivalente, hoje, a US $\$ 7.5 \mathrm{mil}$ para contratos de engenharia ou US\$4 mil para outros contratos $\left.{ }^{10}\right)$.

13. As condições a ser estipuladas no ato convocatório da licitação também são derivação direta da fixação do objeto do contrato.

Por expressa determinação constitucional, os requisitos para habilitação são apenas os indispensáveis para a demonstração de capacidade para realizar o objeto do contrato. Há, portanto, proporcionalidade direta entre um e outro. A apreciação própria da Administração na fixação de condições de participação e de julgamento das propostas é exercida, também aqui, em um quadro muito limitado.

14. A partir da fixação dessas condições de habilitação e de julgamento das propostas, suprime-se qualquer atuação discricionária da Administração no procedimento licitatório.

$\mathrm{O}$ art. $3^{\circ}$ da Lei de Licitações, ao especializar, para o procedimento licitatório, os princípios constitucionais gerais da Administração, consagra a vinculação ao instrumento convocatório e o julgamento objetivo como princípios básicos da licitação.

Isso exige que, de um lado, o ato convocatório contenha critérios suficientes para a aferição dos requisitos de habilitação e dos critérios de julgamento, afastando-se a necessidade de qualquer avaliação subjetiva por parte dos agentes públicos. De outro, impõe que a Administração se paute pelas regras assim fixadas, sendo-lhe vedado rever, no caso concreto, as condições estipuladas (o que não the impede a

$10 \mathrm{O}$ art. 24, parágrafo único, na redação que lhe foi atribuída por alteração legislativa de 1998 , elevou esses valores para o equivalente a US\$15 mil e US\$8 mil, respectivamente, quando se tratar de contratos realizados por sociedades de economia mista, empresas públicas e autarquias ou fundaçōes qualificadas como agências executivas. Essa alteração colaborou fortemente para a redução dos casos de licitação nas contrataçōes realizadas pelas empresas estatais. Por outro lado, como, até o momento, há apenas uma autarquia qualificada no Brasil como agência executiva (o INMETRO), não houve grande relevância prática desse dispositivo em relação a esses entes da Administração. 
estipulação de novas regras, com a publicidade e a antecedência cabíveis, ou mesmo a revogação da licitação).

15. Esses princípios são instrumentais para a realização dos objetivos da licitação, explicitados também no art. $3^{\circ}$ da Lei de Licitações: realizar o princípio constitucional da isonomia e selecionar a proposta mais vantajosa para a Administração.

Trata-se de dois objetivos a ser perseguidos de modo conjugado. Não basta preservar a isonomia sem se perseguir a contratação mais vantajosa, assim como é inválida a contratação mais vantajosa se não realizada a isonomia.

16. Com essa preocupação, a Lei de Licitações define um procedimento minucioso, a partir da estipulação de modalidades de licitação (concorrência, tomada de preços, convite, leilão e concurso), cada uma com seus requisitos e procedimentos próprios, e de tipos de licitação (menor preço, melhor técnica, técnica e preço e maior lance ou oferta), definidos a partir de certos critérios de julgamento e de procedimento.

16.1. As três primeiras modalidades de licitação (concorrência, tomada de preços e convite) são aplicáveis genericamente, a depender do valor da contratação, da natureza e complexidade do objeto contratado ou de alguma determinação legal específica.

Assim, por exemplo, a concorrência é a modalidade obrigatória para contratos de engenharia de valor superior a R $\$ 1,5$ milhão (atualmente cerca de US\$750 mil) ou outros de valor superior a $\mathbf{R} \$ 650 \mathrm{mil}$ (atualmente cerca de US\$325 mil), para contratos de concessão de serviços públicos ou de direito real de uso de bem público, para negócios com bens imóveis e nas licitações internacionais. Os limites são inferiores para as outras modalidades.

16.2. A distinção fundamental entre elas, embora não a única, está nos requisitos para a participação.

16.2.1. Na concorrência, podem participar genericamente quaisquer interessados que exibam, com a sua proposta, a documentação necessária para a comprovação dos requisitos de habilitação. Na tomada de preços, os participantes devem estar cadastrados perante a Administração ou requerer sua inscrição no cadastro, com a documentação pertinente, até três dias antes da abertura das propostas. No convite, a Administração dirige a convocação a um certo número de fornecedores cadastrados, embora se admita que outros não cadastrados também possam formular proposta mesmo não tendo recebido o convite.

16.2.2. Em todas essas modalidades, há um encadeamento de atos (já na fase externa da licitação) consistente sinteticamente no (a) recebimento das propostas e documentos de habilitação, (b) abertura, em sessão pública, dos documentos de habilitação, (c) decisão acerca da habilitação, com os recursos cabíveis, (d) abertura, em sessão pública, das propostas, (e) julgamento das propostas, com os recursos cabíveis, (f) homologação da licitação e adjudicação do contrato ao vencedor.

16.2.3. O importante é notar que há duas etapas fundamentais, consistentes no exame dos documentos de habilitação e no julgamento das propostas.

Ou seja: antes de ter sua proposta avaliada, cada licitante deve comprovar, através de documentos e segundo critérios previstos na lei e explicitados no ato convocatório, sua capacidade para realizar o objeto do contrato. Esse exame é feito 
em relação a todos os licitantes. Somente os que ultrapassam esta fase submetem-se ao julgamento das propostas.

16.2.4. Além disso, as propostas são firmes. Não admitem alteração. São apresentadas em envelopes lacrados e, após ultrapassada a fase de habilitação, não podem ser retiradas pelo licitante. O licitante é punível caso não honre a sua proposta vencedora.

16.3. As duas outras modalidades de licitação são específicas.

16.3.1. O leilão destina-se à venda, mediante lances, de determinados bens (especialmente bens móveis) da Administração.

Tem tido ampla aplicação também no processo de privatização, com base em legislação especial.

16.3.2. O concurso busca selecionar contratado para a realização de trabalho técnico, científico ou artístico, mediante prêmio ou remuneração ao vencedor.

17. Em junho de 2000 , a Medida Provisória $n^{\circ} 2.026$ criou nova modalidade de licitação, denominada pregão. A origem dessa nova modalidade está na Lei Geral de Telecomunicações, que a previa (em termos similares mas não idênticos) para as contratações da ANATEL (Agência Nacional de Telecomunicações).

Embora previsto como aplicável apenas à União, o pregão tem sido interpretado como objeto de norma geral de licitações, portanto disponível também aos demais entes da Federação. Trata-se de modalidade aplicável às contratações mais simples de bens e serviços comuns, relacionados pelo Poder Executivo no Decreto n 3.555 , de agosto de 2000 .

18. Há duas peculiaridades principais.

18.1. A primeira é a de que há uma inversão nas fases de habilitação e julgamento. A aceitação preliminar das propostas é feita mediante mera declaração do licitante de que preenche os requisitos de habilitação. Passa-se ao julgamento de todas as propostas. Definido um vencedor, examinam-se os documentos de habilitação apenas deste. Se for habilitado, os documentos dos demais nem mesmo são examinados. Caso contrário, verifica-se a habilitação do segundo colocado e assim por diante.

O objetivo dessa inversão é tornar mais rápido o procedimento, evitando-se que os litígios comuns na fase de habilitação produzam atraso sobre o resultado final da licitação.

18.2. O outro ponto peculiar é a possibilidade de uma disputa quanto às propostas de preço.

Uma vez apresentadas as propostas, pelo menos três delas são classificadas para a disputa por lances. Os licitantes disputam entre si pela oferta de menor preço para a Administração.

O valor inicial da proposta, portanto, não é definitivo. Pode ser reduzido na âmbito da disputa por lance.

19. Essa inversão das fases de habilitação e julgamento respondeu a uma preocupação já antiga na interpretação e aplicação da Lei de Licitações no Brasil.

Percebeu-se que o exame dos documentos de habilitação de todos os licitantes produzia (como ainda produz) uma rica fonte de litígios e disputas entre os participantes da licitação. Essas disputas refletem-se em recursos administrativos e medidas 
judiciais que acabam por postergar, por prazos longos e indetermináveis, a conclusão da licitação.

20. Essas disputas são favorecidas por um espírito formalista que a Administração (e mesmo o Poder Judiciário) pretende estar consagrado na Lei de Licitações do Brasil.

Imagina-se que a Lei exige, como instrumento para a realização da isonomia e do caráter competitivo da licitação, a aplicação rigorosa e literal dos dispositivos do ato convocatório, de modo que a mais leve desconformidade entre a documentação ou a proposta e as disposições do ato convocatório deva conduzir à inabilitação ou à desclassificação do licitante - tenha ou não sido cumprida a finalidade para a qual as disposições do ato convocatório são postas.

21. Essa visão formalista pretende-se amparada em um conjunto de regras da Lei de Licitações. $O$ art. $3^{\circ}$ da Lei prevê, como visto, o princípio da vinculação ao instrumento convocatório. $O$ art. 41 estabelece que " $A$ Administração não pode descumprir as normas e condições do edital, ao qual se acha estritamente vincula$d a$ ". $\mathrm{O}$ art. $43, \S 3^{\circ}$, faculta à autoridade que promove a licitação "... a promoção de diligência destinada a esclarecer ou a complementar a instrução do processo, vedada a inclusão posterior de documento ou informação que deveria constar originariamente da proposta".

A aplicação literal dessas regras pode transformar a licitação em uma disputa de destreza, em que se premia não a maior capacidade para se realizar o objeto a ser contratado mas a maior aptidão para cumprir os requisitos do ato convocatório. Protege-se a isonomia e a competitividade de modo tão exacerbado que se frustra a economicidade e o próprio interesse público na contratação mais vantajosa.

Embora não se possa descurar da isonomia em nome de um interesse público indefinível e difuso (inclusive porque a Lei de Licitações é manifestação eloquiente de um controle de meios da Administração), a isonomia na participação em licitações deve ser medida e aplicada à luz da finalidade da realização de licitação.

22. A aplicação formalista da Lei de Licitações já produziu exemplos drásticos, que felizmente vêm sendo corrigidos por uma linha segura de jurisprudência do Superior Tribunal de Justiça (não atuando como órgão supremo na interpretação da lei federal no Brasil mas em sua competência originária para o julgamento de mandados de segurança).

22.1. Em 1997, em uma licitação de porte gigantesco, realizada pelo Ministério das Comunicações do Brasil para a concessão da telefonia celular no Estado de São Paulo, um dos licitantes formulou proposta vencedora de aproximadamente $R \$ 1,3$ bilhão (na época, aproximadamente US $\$ 1.2$ bilhão). O segundo colocado formulou proposta de cerca de $R \$ 1,2$ bilhão. A diferença era de $R \$ 102$ milhões, na época pouco menos de US\$100 milhões.

O edital de licitação previa que os valores deveriam ser indicados em algarismos e por extenso. $O$ licitante vencedor deixou de indicar o valor por extenso. Além disso, em lugar de utilizar pontos para separar as centenas, como se faz no Brasil, empregou a notação norte-americana, separando as centenas com vírgulas. Por esses fundamentos, sua proposta foi desclassificada. 
A questão foi submetida ao Superior Tribunal de Justiça que, por maioria de votos, anulou a decisão e determinou que esse licitante fosse considerado vencedor" A decisão, proferida em março de 1998, tornou-se precedente importante na consagração de uma linha de jurisprudência avessa ao excesso de formalismo na aplicação da Lei de Licitações ${ }^{12}$. Fixou-se o entendimento de que as exigências do ato convocatório são instrumentais e somente podem gerar a rejeição do licitante ou de sua proposta na medida em que não se tenha podido atingir a mesma finalidade por outra via. No caso examinado, o Tribunal reconheceu que a proposta permitia saber com certeza o valor proposto, tornando sem sentido o reconhecimento de algum defeito na desconformidade com o ato convocatório.

22.2. Em recurso julgado há cerca de um mês, o tema do formalismo na aplicação da Lei de Licitações foi submetido ao Supremo Tribunal Federal (também no exercício de sua competência recursal em mandados de segurança, não como órgão de julgamento final de questões de constitucionalidade).

Tratava-se de licitação para a aquisição de urnas eletrônicas para votação em todo o Brasil, no valor aproximado de $\mathrm{R} \$ 196$ milhões. O licitante classificado em segundo lugar, com proposta pouco superior, impetrou mandado de segurança buscando a desclassificação do vencedor sob o fundamento de que, descumprindo o edital, não indicara o preço unitário de alguns componentes do produto. $O$ mandado de segurança foi denegado e, em recurso, o Supremo Tribunal Federal confirmou a decisão ${ }^{13}$.

A importância da decisão está em que o acórdão reconheceu expressamente a existência da desconformidade com o ato convocatório, não a considerando relevante por não haver nenhum risco efetivo de dano ao interesse público. Acolheu parecer do Ministério Público nos termos seguintes: “... a vinculação ao instrumento editalício deve ser entendida sempre de forma a assegurar o atendimento do interesse público, repudiando-se que se sobreponhain formalismos desarrazoados. Não fosse assim, não seriam admitidos nem mesmo os vícios sanáveis, os quais, em algum ponto, sempre traduzem infringência a alguma diretriz estabelecida no instrumento editalício".

22.3. A questão, porém, ainda não está definida no âmbito do Supremo Tribunal Federal. Em 8 de agosto de 2000, o Tribunal iniciou o julgamento de recurso em um mandado de segurança em que se impugnava a desclassificação de um licitante por não constar assinatura na sua proposta financeira ${ }^{14}$. $\mathrm{O}$ relator, Min. Maurício

$111^{\text {a }}$ Seção. MS n 5.418/DF, Rel. Min. Demócrito Reinaldo, maioria, j. 25.3.1998, publ. DJU 1.6.1998.

12 Nesse sentido, confiram-se as seguintes decisões recentes do Superior Tribunal de Justiça: $1^{\mathrm{a}}$

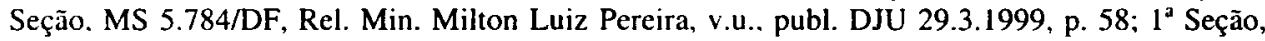

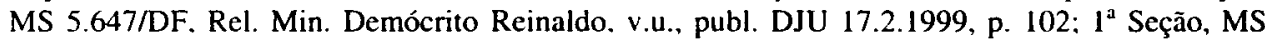
5.607/DF, Rel. Min. Garcia Vieira, v.u., publ. DJU 3.11.1998, p. 5: $1^{a}$ Seção, MS 5.655/DF, Rel. Min. Demócrito Reinaldo, publ. em RSTJ 113/44-51.

$131^{\text {a }}$ Turma, ROMS n 23.714-1/DF, Min. Sepúlveda Pertence, v.u., j. 5.9.2000, publ. DJU 13.10.2000.

14 RMS 23.640/DF. 
Corrêa, e o Min. Nelson Jobim, votaram pela manutenção da desclassificação. O Min. Marco Aurélio votou pelo provimento do recurso, entendendo que a abertura da proposta em sessão pública, retratada em ata, sanava a irregularidade. Houve pedido de vista do Min. Néri da Silveira e o julgamento aguarda prosseguimento.

22.4. Vem-se firmando, assim, no Poder Judiciário, uma linha de interpretação instrumental da Lei de Licitações. Entende-se que as irregularidades somente podem conduzir à eliminação de concorrentes quando frustrada a finalidade para a qual é prevista a disposição editalícia descumprida pelo licitante.

De qualquer modo, o rigor formal na aferição do cumprimento do ato convocatório é um dado a ser tomado em conta nos trabalhos de harmonização em curso no âmbito do Mercosul.

\section{IV - O tratamento de licitantes estrangeiros no Brasil}

23. Há um último tópico relevante para o exame do regime jurídico das licitações no Brasil, especialmente considerando a necessidade de harmonização no âmbito do Mercosul.

Trata-se da investigação sobre a existência (ou não) de preferências para os licitantes nacionais nos contratos administrativos.

24. A legislação infraconstitucional brasileira previa determinadas preferências para empresas brasileiras de capital nacional, para produtos nacionais e para empresas brasileiras.

Havia regra definindo que essas empresas e produtos teriam preferência em caso de empate (art. $3^{\circ}, \S 2^{0}$, da Lei de Licitações). Havia previsão em lei específica de vantagens na contratação pública de bens e serviços de informática e automação quando produzidos por empresas brasileiras de capital nacional (art. $3^{\circ}$ da Lei $\mathrm{n}^{\circ}$ 8.248/91 e Dec. $\mathrm{n}^{\circ} 1.070$ ).

25. Essas regras perderam seu fundamento de validade com a edição da Emenda Constitucional $n^{\circ} 6$, de 1995 , que suprimiu o conceito de empresa brasileira de capital nacional.

Não há a consagração, no Brasil, de preferência para a contratação pública de bens ou serviços produzidos por empresas de capital nacional. Entende-se, além disso, que todas as preferências para brasileiros nas contratações públicas foram suprimidas com a alteração constitucional. Essa posição já foi firmada até mesmo pelo Tribunal de Contas da União, conforme relata MARÇAL JUSTEN FILHO ${ }^{15}$

26. Em todas as licitações, no Brasil, são admitidos licitantes nacionais e estrangeiros.

Há licitações especificamente internacionais, em que as regras são adaptadas à participação de estrangeiros. Porém, em qualquer licitação, desde que cumpridos os

Ob. cit., p. 87. 
trâmites necessários à atuação empresarial regular no Brasil (como a autorização prévia para funcionar no Brasil a que alude o art. 64 do Dec.-Lei $n^{\circ} 2.627 / 40^{16}$ ), os licitantes estrangeiros recebem tratamento rigorosamente idêntico ao dos licitantes nacionais.

\section{$\mathrm{V}$ - O estado atual do tema no âmbito do Mercosul}

27. A preocupação dos órgãos do Mercosul com a questão relativa aos contratos públicos foi manifestada já em 1994, através da Decisão $n^{\circ} 20 / 94$ do Conselho do Mercado Comum.

$\mathrm{Na}$ ocasião, indicou-se que as medidas associadas ao regime de compras governamentais, ao lado de outras, poderiam configurar políticas públicas que distorcem a competição, especialmente em face da preferência outorgada a agentes econômicos nacionais. Deliberou-se pela constituição de uma comissão para a discussão ampla do tema.

27. Houve iniciativa mais específica sobre a questão em 1997. Através da Resolução no 79/97, o Grupo Mercado Comum decidiu criar um Grupo Ad Hoc "Compras Governamentais", destinado a estabelecer proposta para um regime de compras governamentais de bens e serviços.

Esse grupo apresentou seus primeiros resultados em 1998. Através da Resolução $n^{\circ}$ 34/98, o Grupo Mercado Comum aprovou as diretrizes para elaboração do regime de compras governamentais no Mercosul.

Segundo essas diretrizes, os pontos relevantes para o marco normativo comum seriam os seguintes:

a) tratamento nacional: deve-se outorgar aos bens, serviços e fornecedores de qualquer das partes tratamento não menos favorável que o outorgado aos nacionais;

b) cobertura: deve-se definir os entes da Administração e os bens e serviços abrangidos pelo regime; e

c) regras de transparência: procedimentos que garantam a efetividade e 0 cumprimento dos objetivos, garantindo o acesso à informação e o exercício de direitos.

28. O prazo inicialmente fixado para a negociação do anexo sobre a cobertura da disciplina comum venceu em junho de 1999. A Resolução $n^{\circ} 81 / 99$ prorrogou o prazo para a conclusão dos trabalhos até junho de $2000^{17}$.

16 Deve-se apontar que o procedimento para a obtenção da autorização não é simples e pode funcionar como barreira burocrática ao ingresso de licitantes estrangeiros.

17 Já em 2000, o Grupo Mercado Comum criou, através da Resolução n 44/2000, um outro Grupo Ad Hoc destinado à elaboração de um marco normativo sobre as concessões - especialmente, segundo a resolução, as relacionadas com obras públicas e privatizações. Nos termos dessa resolução, os trabalhos do Grupo de Concessōes deverão ser apresentados até dezembro de 2000 , valendo-se dos resultados já obtidos pelo Grupo de Compras Governamentais. O Grupo não foi instalado até o momento. $O$ projeto de Protocolo exclui as concessões de seu âmbito de aplicação (art. $2^{\circ}$, item 5). 
Embora sem prorrogação formal, o Grupo vem promovendo reuniões periódicas, com pautas variadas. A última está ocorrendo em Brasília nos dias 25 e 26 de outubro de 2000, concomitantemente à realização deste Congresso.

29. Até a reunião anterior, ocorrida em 13 e 14 de setembro de 2000, o Grupo já havia produzido um extenso projeto de protocolo sobre compras governamentais e propostas diversas acerca da harmonização da legislação sobre licitações.

29.1. O projeto de Protocolo ${ }^{18}$ reconhece os princípios fundamentais do regime das licitações no Brasil, explicitados no art. $1^{\circ}$ da Lei de Licitações (art. $1^{\circ}$, item 2 , do Protocolo). Prevê regras sobre seu âmbito de aplicação (ampla a qualquer contratação dos Estados-Membros - art. $2^{\circ}$, item 1 - que exceder os limites nacionais de dispensa de licitação - art. $2^{\circ}$, item 2 ), ressalvando a exclusão, em princípio, das licitações baseadas em financiamento estrangeiro (art. $2^{\circ}$, item 4$)^{19}$. Disciplina os requisitos de desempenho anterior e técnicos (arts. $8^{\circ}$ e $9^{\circ}$ ), inclusive com a previsão de regras comuns sobre entidades certificadoras (art. 13) e sobre cadastros públicos. Há um capítulo próprio (arts. 16 a 29) sobre o procedimento licitatório, com a previsão de três espécies de contratação: licitação pública, licitação privada e contratação direta - assimiláveis, em linhas gerais, à concorrência e tomada de preços (licitação pública) e ao convite (licitação privada).

29.2. Quanto à contratação direta, há uma previsão exaustiva de hipóteses, que unificam os casos tratados no Brasil como de inexigibilidade e de dispensa. Diversas das hipóteses contempladas na Lei de Licitações não estão previstas no Protocolo, o que exigirá uma definição precisa sobre os efeitos sobre o direito interno que se pretende extrair do Protocolo. Como o texto do Protocolo afirma que sua aplicação deve-se dar em conjunto com o direito interno, supõe-se que essa relação de hipóteses não afastaria outros casos previstos internamente. Porém, pode haver dificuldade de aplicação conjunta das regras comunitária e interna nesses casos, uma vez que um Estado-Membro pode vir a impugnar a contratação direta de um nacional de outro Estado-Membro em situação não prevista no Protocolo como de ausência de licitação. Considerar que as regras internas não contempladas no Protocolo seriam inaplicáveis em face de interesses de nacionais dos outros Estados-Membros também produziria dificuldade invencível, em face da insegurança (que não se poderia admitir) quanto à legitimidade ou não da licitação. A única solução possível parece ser uma disciplina clara e bem definida sobre os limites das hipóteses de contratação direta, definindo-se que a previsão de certos casos de contratação direta no Protocolo não impede que isso ocorra também em outras situações.

29.3. Por fim, art. 28, item 6, do projeto de Protocolo inclui uma regra de preferência de produtos, serviços e fornecedores oriundos de Estados-Membros do Mercosul, assegurando-lhes o direito à contratação desde que a diferença entre o seu preço e o ofertado pelo licitante vencedor não exceda 3\% (três por cento).

18 Adota-se aqui a redação vigente até a reunião de 13 e 14 de setembro de 2000 .

19 Regra similar, embora prevendo a aplicação de certos princípios da lei brasileira, consta do art. 42 da Lei de Licitaçōes. 
A exigência de igualdade entre os licitantes no Brasil, como já exposto, tornaria questionável a constitucionalidade de regra dessa natureza em face dos princípios da ordem econômica vigentes no Brasil. Se não é viável o estabelecimento de preferências em favor de licitantes nacionais, menos ainda seria possível a atribuição de preferência a licitantes do Mercosul, com base no Protocolo.

Não nos parece, porém, que a atual redação da Constituição Federal do Brasil possa ser interpretada de modo a vedar qualquer discriminação em favor de licitantes nacionais ou regionais. Apenas se excluiu a previsão expressa dessa preferência. Devem ser observados critérios de proporcionalidade e razoabilidade e atendidos fatores reais de discriminação e valores constitucionais como os consagrados no art. $3^{\circ}$, II (objetivo fundamental de "garantir o desenvolvimento nacional") e no art. $4^{\circ}$, parágrafo único ("A República Federativa do Brasil buscará a integração econômica, política, social e cultural dos povos da América Latina, visando à formação de uma comunidade latino-americana de nações"). Nessa linha, desde que atendidos esses critérios, fatores e valores, consideramos possível cogitar-se do estabelecimento de preferências nacionais ou regionais.

\section{VI - Conclusão}

30. Como visto, há no Brasil um quadro jurídico minucioso, de origem constitucional e consagrado em textos legais, que estabelece regras de transparência na seleção de contratados pelo Poder Público. Na atual situação legislativa, essas regras são aplicáveis à integralidade dos contratos celebrados pela Administração Pública direta e indireta - definindo-se, desse modo, a cobertura ou a abrangência que se dá às regras sobre licitações no Brasil.

O Brasil também já suprimiu, desde 1995 e através de emenda constitucional, o tratamento diferenciado para estrangeiros em relação às compras governamentais. Restam apenas barreiras de natureza burocrática, relacionadas com requisitos genéricos para a atuação empresarial de estrangeiros no País. Os licitantes estrangeiros, inclusive os oriundos de países do Mercosul, já recebem, no Brasil, o tratamento de nacionais. Não há atualmente a previsão de vantagens para licitantes oriundos do Mercosul, embora nos pareça - ao contrário do que vem sendo afirmado no Brasil - que seja possível o estabelecimento de vantagens razoáveis dessa natureza.

Essas condições formam um quadro jurídico estável, claro e favorável à adaptação do regime licitatório brasileiro às diretrizes que venham a ser estabelecidas para a harmonização do sistema de compras governamentais no âmbito do Mercosul. 